Ankara Ecz. Fak. Mec.

13. 206 (1983)
J. Fac. Pharm Ankara

13. 206 (1983)

\title{
Nikotinamid Adenin Dinükleotid İnhibisyonun Kolesterol Metabolizması İle İlişkisi I. Total Kan Kolesterol Seviyesine Etkisi
}

The Relation Between the Inhibition of Nicotinamide Adenin Dinucleotide and the Cholesterol Metabolism I. Effects on the Blood Cholesterol Level

Bilge (Uzalp) GÖNÜL*

\section{GİRIŞ}

Bundan önceki çalışmamızda fare ve sıçanlarda nikotinamid adenin dinükleotid (NAD) inhibisyonu için 6-amino nikotinamid (6-AN) ile 6-ANAD türevi oluşturma yöntemleri seçimi ve kontrolü gerçekleştirilmişti (16). Bu çalışmamızda NAD inhibisyonunun total kan kolesterol miktarında ne gibi değişiklik yaptığı araştırılmış, NADP m bedende kolesterol yapım ve yıkımında oynadığı rol göz önüne alınarak sonuçlar tartışılmıştır.

\section{DENEYSEL KISIM \\ MATERYAL ve YÖNTEM}

Deneylerde 15-25 gram ağırlığında yetişkin erkek fareler (ICR) ve 180-250 gram ağırlığında yetişkin erkek sıçanlar (Wistar rat) kullanıld. Deney hayvanları onar ve beşerlik gruplar halinde $23^{\circ} \mathrm{C}$ de 12 saat 1şıklı, 12 saat karanlık tutulan havalandırmalı odada pelet yem ve suyla serbest olarak beslendiler.

Redaksiyona verildiği tarih: 6 Temmuz 1983

* Tıp Bilimleri Bilim Dalı, Eczacılık Fakültesi, Ankara Üniversitesi. 
Deney hayvanları kontrol, misır yağı, klofibrat, klofibrat-f 6-AN, 6-AN, nikotin amid (NA), NAD, heksobarbital ve heksobarbital + 6-AN gruplarına ayrılarak aşă̆ıdaki dozlarda uygulama yapild.

Farelere $200 \mathrm{mg} / \mathrm{kg}$, sıçanlara $10,15 \mathrm{mg} / \mathrm{kg}$ dozda $6-\mathrm{AN}$ (Sigma) (3) ve $0.5 \mathrm{mmol} / \mathrm{kg}$ klofibrat (DİF) (9), çözücü olarak $1.2 \mathrm{ml} / \mathrm{kg}$ mısır yağı (Wako), kontrol amacıyla $13.25 \mathrm{mg} / \mathrm{kg}$ nikotinamid ve $72 \mathrm{mg} / \mathrm{kg}$ nikotinamid adenin dinükleotid IP yolla uygulandiktan 2 saat ve 20 saat sonra kan toplanarak Zak-Henly metodu (12) ile total kan kolesterolleri saptandi.

$\mathrm{Bu}$ arada 6-ANAD oluşumunun kontrolü Dowex kolondan geçirilen nükleotidlerin $260 \mathrm{~nm}$ deki UV absorbansına göre seçilen örnekleri ile n-propanol-amonyak-su (30:60:10) solvan sistemiyle ayrilan ince tabaka kromatogramlarından, fluoresans aktiviteleri (4, 6, $12,15,16)$ ve alkol dehidrogenaz enzimi aktivitelerinin saptanmasi ile yapılmıştır $(1,13)$.

Ayrıca farelerde heksobarbital (TKS) uyuma süresinin uzayıp uzamadığına bakılarak $(10,11)$ diğer bir kontrol yöntemi de uygulanmiştır.

Deney sonuçları istatistiksel olarak "t testi" ile değerlendirilmiştir.

\section{BULGULAR}

Deney sonuçları 4 tablo halinde gösterilmiştir. Tablolarda verilen kan kolesterol değerleri gruplara ait aritmetik ortalamalardır. Çözücü uygulanan gruplar kontrol grubu olarak kabul edilmiştir.

Tablo I. Kontrollar ve çözücülerle $10 \mathrm{mg} / \mathrm{kg} 6-\mathrm{AN}$ ile NAD inhibisyonu yapılmış yetişkin erkek sıçanlarda, uygulamadan 20 saat sonraki total kan kolesterollerini ve istatistik değerlendirmelerini göstermektedir.

Tablo II. çözücü ve kontroller 2 saat, 6-AN ve NAD etkilerinin görülebilmesi için 20 saat önce uygulandığında yetişkin erkek sıçanların total kan kolesterol seviyelerini göstermektedir. Bu grupta 6-AN $15 \mathrm{mg} / \mathrm{kg}$ olarak daha yüksek dozda uygulanmıştır. 
Tablo I. NAD İnhibisyonunun Sıçanlarda Total Kan Kolesterol Miktarlarına Etkisi.

\begin{tabular}{|c|c|c|c|c|}
\hline Grup & $\begin{array}{l}\text { Denek } \\
\text { Sayis1 }\end{array}$ & \multicolumn{3}{|c|}{$\begin{array}{l}\text { Total Kan Kolesterol } \\
\text { Miktar } \mathrm{mg} / 100 \mathrm{ml} \text {. }\end{array}$} \\
\hline A. Kontrol & 4 & 104.5 & & \\
\hline $\begin{array}{l}\text { B. Misır yağı } \\
1.2 \mathrm{ml} / \mathrm{kg}\end{array}$ & 4 & 89.75 & $0.02>P>0.01$ & $(A-B)$ \\
\hline $\begin{array}{l}\text { C. Klofibrat } \\
0.5 \mathrm{mmol} / \mathrm{kg}\end{array}$ & 4 & 76.75 & $0.05>\mathrm{P}>0.02$ & $(B-C)$ \\
\hline $\begin{array}{l}\text { D. Klofibrat + } \\
\text { 6-AN }\end{array}$ & 4 & 103.75 & $0.05>\mathrm{P}>0.02$ & $(B-D)$ \\
\hline $\begin{array}{ll}\text { E. } & 6-\mathrm{AN} \\
& 10 \mathrm{mg} / \mathrm{kg}\end{array}$ & 4 & 111 & $0.1>\mathrm{P}>0.05$ & $(A-E)$ \\
\hline $\begin{array}{l}\text { F. NA } \\
13.25 \mathrm{mg} / \mathrm{kg}\end{array}$ & 5 & 102 & $0.3>\mathrm{P}>0.2$ & $(A-F)$ \\
\hline
\end{tabular}

Tablo II. NAD inhibisyonunun Siçanlarda Total Kan Kolesterol Miktarlarına Etkisi.

\begin{tabular}{|c|c|c|c|}
\hline Grup & $\begin{array}{l}\text { Denek } \\
\text { Sayısı }\end{array}$ & \multicolumn{2}{|r|}{$\begin{array}{l}\text { Total Kan Kolesterol } \\
\text { Miktarı mg/100 ml. }\end{array}$} \\
\hline A. Kontrol & 7 & 105.9 & \\
\hline B. Misır yağ1 & 9 & 137.44 & $\mathbf{P}<0.001$ \\
\hline C. Klofibrat & 6 & 88.8 & $0.001<\mathrm{P}<0.01(\mathrm{~B}-\mathrm{C})$ \\
\hline $\begin{array}{l}\text { D. Klofibrat }+ \\
\text { 6-AN }\end{array}$ & 8 & 85.4 & $\begin{array}{ll}0.01<\mathrm{P}<0.001 & (\mathrm{~A}-\mathrm{D}) \\
\mathrm{P}<0.001 & (\mathrm{~B}-\mathrm{D})\end{array}$ \\
\hline E. 6-AN $(15 \mathrm{mg} / \mathrm{kg})$ & 9 & 150.77 & $\mathbf{P}<0.001$ \\
\hline F. NAD & 7 & 137.14 & $\mathbf{P}<0.001$ \\
\hline
\end{tabular}

Tablo III. Kontrol ve çözücülerle, $200 \mathrm{mg} / \mathrm{kg}$ dozda 6-AN ile NAD inhibisyonununun 20 saat uygulama sonunda yetişkin erkek farelerin kan kolesterol seviyelerine etkilerini ve istatistik değerlendirmelerini göstermektedir.

Tablo IV. $15 \mathrm{mg} / \mathrm{kg}$ dozda 6-AN uygulamasının sıçanlarda heksobarbital uyuma zamanına ve dokulardaki heksobarbital miktarlarına etkileriyle istatistik değerlendirmelerini göstermektedir. 
Tablo III. NAD İnhibisyonunun Farelerde Total Kan Kolesterol Miktarlarına Etkisi.

\begin{tabular}{|c|c|c|c|c|}
\hline Grup & $\begin{array}{l}\text { Denek } \\
\text { Sayisı }\end{array}$ & \multicolumn{3}{|c|}{$\begin{array}{l}\text { Total Kan Kolesterol } \\
\text { Miktarı mg/100 ml. }\end{array}$} \\
\hline A. Kontrol & 5 & 140.2 & & \\
\hline $\begin{array}{l}\text { B. Misır yağ } 1 \\
(12 \mathrm{ml} / \mathrm{kg})\end{array}$ & 6 & 143.83 & & \\
\hline C. Klofibrat & 6 & 136.5 & $P=0.6$ & $(B-C)$ \\
\hline D. $6-\mathrm{AN}$ & 6 & 168.83 & $0.2>\mathrm{P}>0.1$ & (A-D) \\
\hline
\end{tabular}

Tablo IV. NAD İnhibisyonunun Sıçanlarda Heksobarbital Uyuma Süresi ve Heksobarbital Doku Seviyelerine Etkisi.

\begin{tabular}{|c|c|c|c|c|c|}
\hline \multirow[b]{2}{*}{ Grup } & \multirow{2}{*}{$\begin{array}{l}\text { Uyuma za- } \\
\text { manı (dk) }\end{array}$} & \multirow{2}{*}{$\begin{array}{c}\text { Kan Hekso- } \\
\text { Barbital } \\
\text { Miktar1 } \\
\mathrm{Mg} / \mathrm{ml}\end{array}$} & Doku & $\begin{array}{c}\text { Heksobarbital } \\
\mathrm{Mg} / \mathrm{gr}\end{array}$ & Miktarı \\
\hline & & & Beyin & Karaciğer & Böbrek \\
\hline $\begin{array}{l}\text { Heksobar- } \\
\text { bital* }\end{array}$ & $\begin{array}{l}12 \\
11 \\
14 \\
15 \\
25\end{array}$ & $\begin{array}{l}46.5 \\
48 \\
52.7 \\
48 \\
52.2\end{array}$ & $\begin{array}{l}17 \\
17.5 \\
16 \\
13\end{array}$ & $\begin{array}{l}41 \\
55 \\
62 \\
48\end{array}$ & $\begin{array}{l}43 \\
32 \\
49 \\
34 \\
41\end{array}$ \\
\hline Ortalama & 15.4 & 49.48 & 15.87 & 51.5 & 39.8 \\
\hline $\begin{array}{l}\text { Heksobarbi- } \\
\text { tal-6-AN** }\end{array}$ & $\begin{array}{l}40 \\
21 \\
26.5 \\
20.5 \\
29 \\
26\end{array}$ & $\begin{array}{l}63.2 \\
56 \\
48 \\
46 \\
40\end{array}$ & $\begin{array}{l}37.3 \\
40 \\
25 \\
23 \\
22 \\
23\end{array}$ & $\begin{array}{l}53 \\
61 \\
51 \\
61 \\
48\end{array}$ & $\begin{array}{l}33 \\
32 \\
29 \\
35 \\
34 \\
29\end{array}$ \\
\hline Ortalama & 27.16 & 50.64 & 28.38 & 54.8 & 32 \\
\hline $\mathrm{T}$ test & $\begin{array}{l}0.02> \\
\mathrm{P}>0.01\end{array}$ & $\mathrm{P}>0.7$ & $\begin{array}{l}0.02> \\
\mathrm{P}>0.01\end{array}$ & $\mathrm{P}>0.5$ & $\begin{array}{l}0.05> \\
\mathrm{P}>0.02\end{array}$ \\
\hline
\end{tabular}

* $100 \mathrm{mg} / \mathrm{kg}$ intraperitoneal tek doz uyguland 1 .

** $100 \mathrm{mg} / \mathrm{kg}$ IP heksobarbital ve bundan 18 saat önce $15 \mathrm{mg} / \mathrm{kg}$ dozda 6-AN, IP yoldan uygulanmıştır. 


\section{TARTIŞMA ve SONUÇ}

Tablolardan da izlenebileceği gibi 6-AN uygulaması sonunda NAD in inhibisyonu total kan kolesterol seviyesini istatistiksel açıdan anlamlı olarak yükseltmektedir. Bu yükselme NAD inhibisyonu ile doğru orantılıdır (Tablo I, II). Bu etkinin organizmada NAD ve NADP sentezinde kullanılan nikotin amid yerine 6-AN gibi bir analoğu verilince NAD veya NADP yerine 6-ANAD ve 6-ANADP ile redükte formlarının oluşumu ve kolesterol biyosentez ve yıkımı olaylarında kullanılan NADP lar yerini kompetitif antagonizma ile alarak hidrojen atomu akseptörü olarak görev yapamayıp bu basamaklarda olayı bloke etmesi şeklinde olabileceği akla yatkın gözükmektedir.

Deneylerde kontrol amaci ile uygulanan klofibrat ve nikotinamid beklendiği gibi uzun ve kısa sürelerde kan kolesterolünde düşme yapmıştır. 6-AN ile birlikte uygulama sonunda NAD inhibisyonuna bağlı sonuçlara benzer yüksek bulgular kolesterol miktarındaki değişmelerin bedendeki sentez veya yıkımın enzimatik inhibisyonla durması nedeniyle diyetle alınan kolesterol birikimine bağlanabileceğini düşündürmektedir. NAD uygulamasındaki yükselme ise bazı nedenlerle yıkımdan çok sentez mekanizmasındaki artışa bağlı olabilir.

Tablo I, II, III de görüldüğ̈̈ gibi klofibrat kan kolesterol seviyesinde beklenildiği gibi düşme yapmıştır. Bir çok araştırıcının klofibratın etki mekanizması üzerine birbirine zıt görüşleri vardır. Örneğin; CAYEN klofibratın organizmada klofibrik aside dönerek etki gösterdiğini ve bu etkinin serbest ya $\breve{g}$ asitleri ve triasil gliserol ya $\breve{g}$ asitleri için VLDL sekresyonunu azaltma şeklinde olduğunu ileri sürerken, LAKER diyetle uygulanan klofibratın klofibrik asitten daha etkili olduğunu savunmaktadır $(2,8)$. WHİTE'a göre klofibrat, mikrozomal HMG-Co A nın mevalonat reaksiyonunu önleyerek karaciğerdeki kolesterol biyosentezini inhibe eder (17). Ancak yine LAKER'e göre klofibratla sıçan ve farelerde 18-24 saat içinde peroksizomal proliferasyon olur. Yanısıra mitokondrilerde de artış görülmektedir (8). Peroksizom proliferasyonu oksitlenmiş pahmtoil-CoA artışıla beraberdir, bu da mitokondrial protein artışı ile birlikte olursa oksitlenmiş yağ açili-CoA, serbest yağ asitlerinin $\mathrm{CO}_{2}$ e oksitlenmesi ve resiprok olarak VLDL salınım ve csterifikasyonu ile ilgilidir. Karaciğerde 
serbest ya $\breve{g}$ asiti esterifikasyonu azalmasıyla VLDL salınımındaki azalma, bu yapının integral parçası olan kolesterolde de düşme yapacaktır. İşte LAKER'e göre klofibrat, serbest yă̆ asitlerinin karaciğer hücrelerine girip serum seviyesinin düşmesini sağlamaktadır.

$\mathrm{Bu}$ arada klofibratın uzun ve kısa süreli uygulama sonuçlarının farklı olduğu da tesbit edilmiştir.

20 saat süreli deney sonuçlarımızdan da görülebileceği gibi NAD inhibisyonu klofibrat etkisini kaldırmaktadır. Buna karşılık 2 saat süreli uygulamada klofibrat etkisi ortaya çıkmaktadır. Oral olarak klofibrat uygulamasını takiben birçok dokularda 48 saate kadar izlenmiş ve genel olarak klofibrat seviyesinin 6 saatten sonra düşmeye başladı̆̆ı, 12 saatte minimuma ulaşıp, 24 saatten sonra başlangıç değerine ulaşarak yükselmeye devam ettiği gözlenmiştir. (2) Tablo I ve II ve klofibrat ve 6-AN birlikte uygulama sonuçlarında görülen fark önceden NAD inhibisyonu yapılmış deney hayvanlarında serum ve dokulardaki klofibrat seviyesi değişmelerinin de etkisiyle ortaya çıkabilir. Zira kontrollarda ve klofibrat deney grubunda süreye bağlı bir değişiklik gözlenmemektedir.

Bu arada Tablo IV den de görüldüğü gibi 6-AN uygulanmış hayvanlarda heksobarbital uyuma süresi uzamış, beyin heksobarbital seviyesi yüksek bulunmuştur. Bu güne kadar barbitüratlarla yapılmış araştırmalara bakılırsa bu ilaçların sedasyon ve hipnoz oluşturması kateşolamin döngü hızının azalarak biyojenik aldehit birikimine bağlanabilir. Bu da merkezi sinir sisteminde aldehit redüktazların inhibisyonu ile sağlanabilir $(9,10,14)$ Satoh ve çalışma arkadaşlarına göre 6-AN ve hcksobarbitalin birlikte uygulanmalarında oluştuğu varsayılan 6-ANADH (redükte 6-amino nikotinamid adenin diriükleotid), NADH e bağımlı aldehit redüktazların inhibisyonuna neden olmakta ve barbitürat inhibisyonuna eklenerek uyuma süresini uzatmaktadır. O halde Tablo IV de görüldügü gibi uyuma süresinin istatistiksel açıdan anlamlı olarak uzaması ve yine beyin heksobarbital seviyesinin anlamlı olarak artmış olması, inhibisyonun gerçekleştiğine dair bir kanıttır.

Bunun yanısıra 6-AN uygulanan hayvanlarda paralizi ve vücud ısısında düşme görülmüştür, bu gözlemler de diğer araştırıcıların bulgularına uymaktadır (7). 
Sonuçların tümü birlikte değerlendirilecek olursa klofibratlı gruplarda dahil olmak üzere 6-AN uygulamasında oluşan hiperkolesteroleminin nedeni 6-ANAD ve 6-ANADP sentezlenerek kolesterol biyosentez ve yıkımındaki basamaklarda NADP lerin yerini kompetitif antagonizma ile almasıdır, denilebilir. Zira bu şekli ile kofaktör hidrojen atomu akseptörü olarak görev yapamadığından olay bu basamaklarda bloke olmaktadır. Literatürde nikotinik asit veya nikotinamidin uygulanmasında serum kolesterol miktarının düştüğüne dair yayınlanmış bulgular da açıklamamızı desteklemektedir (5).

Sıçanlar ve farelere ait sonuçlardaki doz-yanıt farklılıkları bu 2 türe ait enzimatik değişiklikler olduğunu düşündürmektedir.

\section{ÖZET}

Yetişkin erkek sıçanlarda ve farelerde 6-aminonikotinamid uygulanarak Nikotinamid Adenin Dinükleotid (NAD) inhibisyonu yapılmıştır. Daha sonra bu deneklerde inhibisyon olup olmadı̆̆ $\breve{1}_{\text {hek- }}$ sobarbital uyuma zamanı ve heksobarbital doku seviyeleri kontrol edilerek saptanmıştır. Uyuma zamanının uzaması ve beyin heksobarbital seviyesi artışı ile 6-ANAD oluşumu gösterilen deney hayvanlarında klofibrat kontrol grubu ile karşılaştırılarak kan kolesterol seviyeleri saptanmıştır. Sonuç olarak NAD inhibisyonu yapılan deney hayvanlarında hiperkolesterolemi geliştiği görülmüştür. Ancak bu arada fare ve sıçanların NAD inhibisyonu sırasında doz-yanıt açısından farklılık gösterdikleri saptanmıştır.

\section{SUMMARY}

Nicotinamide adenine dinucleotide (NAD) had been inhibited by the 6-amino nicotinamide (6-AN) administration to the adult male rats and mice. The inhibition was controlled by the longering the sleeping time which was caused by hexobarbital and by the increasing the hexobarbital level in the brain tissue. Meanwhile the blood cholesterol levels of the normal, clofibrate treated and 6-AN treated experimental animals groups were measured.

It has been demonstrated that the blood cholesterol levels were increased by NAD inhibition depending species. 


\section{LİTERATÜR}

1- Bergmeyer, H.U., Methods of Enzymatic Analysis, Vol. 4, 2. Ed., Verlag Chemie Weinheim Academic Press, Berlin, 1974.

2- Cayen, M.N., Ferdinandi, E.S., Greselin, E., Robinson, W.T., Dvornik, D., J.of Pharm.and Exp.Ther., 2oo, 1, 33, 1976.

3- Dietrich, L.S., Frieland, I.M., Kaplan, L.A., J.Biol.Chem., 233: 4, 964-968, 1958.

4- Ewing, G.W., Instrumental Methods of Chemical Analysis, 4.Edit., Mc Graw-Hill Book Comp., New York, 1975.

5- Hansten, P.D., Drug Interactions, 3. Edit., Lea and Febiger, Philedelphia, 1975.

6- Harvey, H., Anal.Biochem., 2g, 58, 1969.

7- Herken, H., Lange, K., Kolbe, H., Biochem.and Biophy.Research Com., 36: 1, 93-100, 1969.

8- Laker, M.E., Mayes, P.A., Biochem.Pharmacol., 28, 2813-2817, 1979.

9- Mayers, F., Janetz, E., Goldfien, A., Review of Medical Pharmacology, Lange Medical Publications, Los Altos, 1978.

10- Minegishi, A., Fukumori, R., Satoh, T., Kitagawa, H., Yanaura, S., Research Com.in Chem.Path. and Pharm., 24; 2, May, 273, 1979.

11- Minegishi, A., Satoh, T., Kitagawa, H., Fukumori, R., J. Pharm.Dyn. 5, 42, 1982.

12- Nakayama, M., Methods in Medical Chemistry, Tokyo University Press, Tokyo, 1978.

13- Roodyn, D.B., Automated Enzyme Assays, North Holland Publishing Coop., Amsterdam, 1970.

14- Satoh, T., Fukumori, R., Minegishi, A., Kitagawa, H., Yanaura, S., Research Com.in Chem.Path.and Pharm., 23: 2, February, 1979.

15- Udenfriend, E., Fluorescence Assay in Biology and Medicine, Academic Press, New York, 1962.

16- Uzalp, B., Ankara Ecz.Fak.Mec, 11: 2, 1981.

17- White, L.W., J.Pharmacol.Exp.Ther., 178, 361-370, 1971. 
Fakülte Profesörler Kurulunun 10.3.1970 tarih ve 358 sayılı Kararı ile Fakülte Mecmuasında yayınlanacak yazılar için tesbit edilen esaslar

1) Dergide, başka bir mecmuada aynı isimle ve aynı tarzda neşredilmemiş orijinal çalışmalar yayınlanır.

2) Yazılar Komisyona verildiği tarih sırasıyla yayınlanır.

3) Metin 15 daktilo sayfasını geçmemek üzere Türkçe veya yabancı dilde yazılabilir. Metin başlığı ve özeti Türkçe ve yabancı dilde yazılacaktır.

Yabancı dilde yazılmış başlık, metin ve özetlerin dil kurallarına uygun olmasının temini, yazara aittir.

4) Yazılar, kâğıdın bir yüzüne, daktilo ile ve normal aralıkla yazılmalı, italik yazılacak kelimelerin altı çizilmeli, klişesi yapılacak grafik, şema, formül gibi şekiller, çini mürekkep ile, aydinger kâğıdına çizilmeli; fotoğraflar parlak kâğıda ve kontraslı olarak çekilmelidir. Şekillerin her biri ayrı kâğıtlarda olmalı ve kâğıdın üzerinde yazarın adı, kaçıncı şekil olduğu, resim altı yazılması istenen ibare kaydedilmelidir.

5) Yazı plânı aşağıdaki şekilde olmalıdır: Konunun takdimi, bulgular, denel kısım, münakaşa, Türkçe özet, yabancı dilde özet, literatür.

Konunun takdimi 2 daktilo sahifesini geçmemeli; materyal, metot ve yapılan ameliyeler "denel kısım" da yer almalı, "münakaşa" kısmı, gerekli ise konmalıdır.

Literatür, metinde parentez içindeki numaralarla belirtilmesi ve metin sonunda bu numaralara uygun olarak sıralanmalıdır. Sırasıyla yazarın soyadı, adının ilk harfi, mecmuanın milletlerarası kullanılan kısaltılmış ismi, cilt numarası (italik), sayfa ve parentez içinde tarih yazılmalıdır.

6) Tashihler yazar tarafından yapılacaktır.

7) Yazara 50 ayrı baskı verilir. 